\title{
The Relationship Between Education Outputs, Education Expenditure, and Economic Growth in Saudi Arabia
}

\author{
Benlaria Houcine ${ }^{1}$, Messen Kerroumia ${ }^{1}$, Emad Abdel Khalek Saber El-Tahan ${ }^{1} \&$ Tarig Osman Abdallah Helal ${ }^{1}$ \\ ${ }^{1}$ Department of Business Administration, Jouf University, Saudi Arabia \\ Correspondence: Benlaria Houcine, Department of Business Administration, Jouf University, Saudi Arabia.
}

Received: January 27, 2021

Accepted: March 7, 2021

Online Published: April 14, 2021

doi:10.5430/rwe.v12n2p320

URL: https://doi.org/10.5430/rwe.v12n2p320

\begin{abstract}
The present study investigated the relationship between education outputs, Education expenditure, and economic growth in Saudi Arabia for the time period of 1986-2016. The results obtained after employing the Autoregressive Distributed Lag (ARDL) model revealed a long-term relationship between the studied variables, an inverse relationship between the number of graduates and growth in the long term, whereas a non-significant positive relationship appeared in the short -term. Findings indicate also that public spending in education has a positive and significant impact on economic growth in the long run. Furthermore, he observed that a $1 \%$ increase in public expenditure in education contributes 18\% increase in GDP per capita in the long run. This is in line with economic theory and previous research showing that expenditure on education leads to a rise in GDP per capita and economic growth rates. The recommendations of this study are fundamental to the Kingdom of Saudi Arabia.
\end{abstract}

Keywords: higher education, education outputs, education expenditure, economic growth, ARDL, GDP per capita, Saudi Arabia

\section{Introduction}

The Kingdom of Saudi Arabia is one of the largest oil producers in the world, with an average daily production of 9.8 million barrels of crude oil, which is equivalent to $30 \%$ of the total production of OPEC members (Fantin, 2016); thus, the oil industry is the basis of the country's economic development (Al-Bassam, 2015). According to the statistics of the Saudi Arabian Monetary Agency (SAMA, 2016) from the eighties of the last century, this industry contributed to half of the country's gross domestic product (GDP). In addition, the Saudi government has heavily relied on oil revenues to cover all government expenditures related to human and economic development, social infrastructure, and communication, among others (Almawishir, 2018). The decline in oil prices in recent years has led to a reduction in expenditures in numerous sectors; in parallel, the announcement of the 2030 Vision resulted in several achievements, including an increase in non-oil revenues by about 90 billion Saudi riyals and a decrease in the budget deficit by more than 30\% (Almawishir, 2018). Further, the Vision has set several objectives; in the aspect of education, this includes providing education opportunities for all in appropriate educational environments, raising the quality of education outputs, increasing the effectiveness of scientific research, and encouraging creativity and innovation. Thus, Saudi Arabia has allocated huge sums from its national budget toward the attainment of education (World Bank, 2010). Considering that this investment makes a significant difference to nations and that such development depends on the speed of human capital growth, education was found to be fundamental - its positive impact is reflected on individuals, the society, and the economy. Schultz (1961) and Becker (1964) stated that investing in individuals through education elevates their earning levels as well as their productivity. Baleav (2014) explained that, through education, individuals can obtain knowledge that makes them active people in the society and economy. Alvena and Muhamed (2013) stated that, in addition to the benefits of education accrued to individuals, such as employment opportunities and high wages, there are other advantages such as a reduction in resource consumption and waste, an increase in qualified and skilled manpower, an increase in productivity, and adaptation to technology. According to Mercan (2014), it improves manufacturing base competitiveness among the economies. Jones (1998) and Alvena and Muhamed (2013) summarized that the human factor is the primary driver of technological development. Wozniak (1987) indicated that the success of some countries in the rapid adoption of modern technology is due to the level of knowledge of their human resources. Schulz (2002) admitted that human capital and technology lead to economic progress. Temple (1999) drew attention to another important aspect, that of 
the educated worker being easy to train; they learn fast, perform intricate tasks, are good at time management, and have a greater interest in work outputs. Glaeser et al. (2004), Sanchez and Cicowiez (2014), Benhabib and Spiegel (1994), and Castelló-Climent and Doménech (2008) believe that education reduces the effects of epidemics and promotes health, reduces poverty as well as gender inequalities, ensures good governance, and increases the country's innovation capacity; they added that employing graduates in different economic sectors helps in increasing the growth rates. Mehmet and Sevgi (2014) stated that one of the goals politicians seek by enhancing the level of education, particularly in developing countries, is to reduce unemployment rates, as is the case in Saudi Arabia; the country sought to reduce the unemployment rate, which was reported to be $5.5 \%$ in 2017, through many plans and policies. It should be further noted that the most significant reason for unemployment is the gap between the demand for and supply of labor in terms of academic qualifications and required skills (Almawishir, 2018).

Therefore, this study was aimed at investigating the impact of education outputs and education expenditure on economic growth in Saudi Arabia for the time period of 1986-2016; moreover, it provides an extensive overview of the existing literature that examines the relationship between education and economic growth.

The present study is distinguished from many others by its focus on educational outputs as a variable that may affect economic growth besides expenditure on education. Further, studies applied to the Kingdom of Saudi Arabia, if any, are rare despite its importance as a representative of many oil-producing countries.

This paper is structured as follows. The second section highlights the literature dealing with the nexus between education expenditure, education output, and economic growth. The following section explains the methodology adopted and describes the data used in the study. The fourth discusses the results, and the final section concludes the paper.

\section{Literature Review}

There have been numerous studies in this field, which have focused on developed as well as developing countries. Some of these dealt with public expenditures and others involved private ones; some focused on education as the fundamental component for investing in human capital, while many included additional aspects such as investment in health; and some were limited to higher education, while others expanded to include the rest of the academic levels. However, they all focused on the impact of education on economic growth rates. The results of a set of studies are as follows:

Mehmet and Sevgi (2014) used the bounds testing approach and concluded that education expenditures had a positive and significant effect on economic growth in Turkey for the period of 1979-2012. They dealt with all stages of education, from primary to university, and mentioned a positive and significant relationship between education expenditure and economic growth, focusing on the necessity of spending in the former due to its significant contributions to economic growth through an increase of opportunities for knowledge transfer. Sergio et al. (2009) studied 19 OECD countries from 1971 to 1998 and found that there was a strong positive relationship between their health and education expenditures and GDP growth and that the impact of public health and education expenditures on economic growth was greater than that of private expenditures; further, it was stronger for health as compared to education. Shahriyar et al. (2020) presented a case study of Azerbaijan in 1995-2018. Using ARDLBT, DOLS, and CCR, the researchers obtained results indicating that government expenditures in education and human capital formation had positive effects on long-term economic growth. Similarly, Lingaraj et al. (2016) sought to understand the relationship between education expenditure and economic growth in 14 Asian countries, including Saudi Arabia, Japan, Malaysia, Philippines, Singapore, and Pakistan, for the period of 1973-2012 by employing balanced panel data. Their study revealed a long-term relationship and a significant statistical impact of expenditures on education and economic growth in all the selected countries. These results were in line with the previous studies conducted by Bassanini and Scarpetta (2001), Gustafsson and Li (2004), Mankiw et al. (1992), Krueger and Lindahl (2001), and Barro and Lee (1993) who studied 129 countries and found a relationship between the two variables in the long run.

Many scholars have studied human capital and the economic growth nexus, including Barro and Sala (2003), Lucas (1988), Jorgenson et al. (1987), and Cohen and Soto (2007), attempting to establish a scale that represents this capital; they used several points, including wage levels, educational level, and age for the same. Jong-Suk and Jong-Wha (2020) collected accurate and comprehensive data on age, gender, education, and wage rate to examine the role that employment played in the GDP and growth rate from 1986 to 2017 in Korea. They found that the main factor that contributed to human capital growth was the continuous improvement in education attainment levels among workers, and the better educated and more productive workforce contributed significantly to economic growth. Lingaraj and Devi (2015) analyzed the relationship between economic growth and educational expenses in India. This study included all the primary, secondary, and higher education stages from 1951 to 2012 . The results of the econometric 
analysis confirmed a long-term equilibrium relationship, and the study concluded that more emphasis should be placed on spending in education and training programs such as vocational education to create more efficient human capital that contributes to economic growth. Yousif (2008) aimed to analyze the role of human capital and explore the impact of investment in education on economic growth for the six Gulf Cooperation Council countries in 19772004 using the Granger causality test. He found the existence of a bidirectional causal relationship between the two variables and that this effect differed between the countries studied. Alvina and Muhammad (2013) conducted a study on seven developed countries and seven developing countries from 1990 to 2006; the results showed a great impact of public education expenditures on economic growth in developing countries as compared to developed countries. The authors explained that the developing countries had greater marginal productivity in the formation of human capital because, despite the developed countries' investment in human capital being greater, the former's workforce was more skilled. Sefa et al. (2017) collected results from 29 studies that empirically investigated the effect of government education expenditure on economic growth. The results showed a positive effect on the growth rates of developed countries in contrast to those of developing countries. When studying the education-economic growth nexus, Çalışkan et al. (2013) found a positive relationship between the quantitative outcomes of secondary and higher education levels and the GDP. Barrow (1991) conducted a study of 98 countries and concluded that the number of enrolled students positively affects the rate of per capita income. Drawing from this study, Telatar and Terzi (2010) pointed out that an increase in per capita income leads to an increase in the number of university graduates. In the same context, by studying 87 countries, Gylfason and Zoega (2003) proved that the number of enrollments in secondary schools with regard to the female category as well as the education expenses changed with the rate of economic growth. Wulong and Ambrose (2015) tried to measure the outputs of the education sector from 1976 to 2005 in Canada, aiming to ascertain the level of productivity of the education sector, using two methods - income-based and cost-based - both of which gave similar results for the growth in educational outcomes. Among the studies that examined the impact of higher education outputs on growth, Jang and Lawrence's study (2014), which adopted research presented by university professors as an indicator of the quality of higher education, included 34 developed countries, and the results indicated that research outputs in science and engineering have the largest positive impact on economic growth, followed by business and economics researches. In the same context, Holm-Nielsen et al. (2013) added that the results of research and those from this era alone are not sufficient. In addition to the scientific production that is poured into building industries and serving the society, universities also need to play a greater role in the creation of researchers. Moreover, Carayannis and Campbell (2009) designed a quadruple helix model aimed at developing a skilled and trained workforce. They also explained the importance of developing talent and the need to focus on investment in this field for the benefit of the university and society. Relatively, Manafi and Marinescu (2013) encouraged more investments in lifelong learning and linked it to the overall output. Agion et al. (2006), in a study applied on OECD countries and 50 US states, investigated the relationship between technological change and educational policies; they indicated that higher education is one of the causes of economic growth, pointing out the importance of quality education which leads to the emergence of more researchers who innovate and expedite the adoption of technology. Another study was conducted by Alo and Kärt (2017) at the regional level in Europe, covering the period of 1998-2008, in which they empirically investigated the relationship between higher education and regional development. They indicated a strong statistically significant relation between knowledge employment, research and development expenditures, and GDP levels. To explore the contribution of physical capital formation and labor input on economic growth as well as examine the relationship between government education expenditure per worker and economic growth in Kenya for the period of 1967-2010, Ojala (2016) employed time series techniques. The findings revealed that the average education expenditure per worker was positively correlated with economic growth. Exogeneity tests indicated that education expenditures are weakly exogenous, thereby suggesting that they cause economic growth and not vice versa.

According to some scholars, and in contrast to the studies listed above, human capital is not a good predictor of economic growth in general and there is a weak relationship between education expenditure and economic growth. Others revealed a negative correlation between the two variables as well, including Benhabib and Spiegel(1994), Zhang (1996), Levine and Renelt (1992), Brauninger and Vidal (1999), Devarajan et al. (1996), Bils and Klenow (2000), Bouzahzah et al. (2002), Mpho (2015), and Keller (2006). Some believe that the reason is the exclusion or inclusion of some variables that explain the phenomenon (Levine \& Renelt, 1992). Takii and Tanaka (2009) stated that it is necessary to pay attention to the diversity of human capital as a decisive element in this relationship.

In general, most studies that addressed this topic focused on the relationship between education expenditures and economic growth. While our study is distinguished by adding the number of graduates as a variable and this what the previous studies have not dealt with Thus, we tried to measure the impact of educations and education expenditures 
on economic growth at the same time, we attempted to find out to which extent these outputs are compatible with the requirements of the Saudi labor market.

\section{Data and Methods}

Table 1. Description of the table

\begin{tabular}{ll}
\hline GDP & Gross domestic product $($ GDP) per capita (Constant 2010 US\$) \\
\hline $\mathrm{T}$ & Total number of graduates $(\mathrm{PhD}$, master's degree, higher diploma, bachelor's degree \\
\hline $\mathrm{G}$ & Education expenditure \\
\hline
\end{tabular}

\subsection{Data}

To study the relationship between education outputs, education expenditure, and economic growth of Saudi Arabia as a case study, all annual time series running from 1986 to 2016 were collected. The GDP per capita (constant 2010 USD), denoted as GDP, was used along with the total number of graduates with ( $\mathrm{PhD}$, master's, higher diploma, bachelor's) degrees denoted as t. Additionally, the education expenditure (current USD) denoted as G was used . Data pertaining to these variables were collected from the World Bank and the website of the Ministry of Education, Saudi Arabia. An algorithm was introduced to the study data. The following table (Table 2) provides descriptions of the study data:

Table 2. Description of the study variables

\begin{tabular}{llll}
\hline Variables & $L N \_G$ & $L N \_G D P$ & $L N \_T$ \\
\hline Mean & 27.52231 & 9.848521 & 10.87164 \\
\hline Median & 27.28949 & 9.846971 & 11.01881 \\
\hline Maximum & 28.67353 & 9.971104 & 12.28553 \\
\hline Minimum & 26.49449 & 9.661109 & 9.537844 \\
\hline Std. Dev. & 0.732013 & 0.078792 & 0.823712 \\
\hline Skewness & 0.295897 & -0.430098 & -0.178534 \\
\hline Kurtosis & 1.681742 & 2.732821 & 1.977493 \\
\hline Jarque-Bera & 2.697032 & 1.047955 & 1.515149 \\
\hline Probability & 0.259625 & 0.592160 & 0.468802 \\
\hline Sum & 853.1915 & 305.3041 & 337.0209 \\
\hline Sum Sq. Dev. & 16.07529 & 0.186248 & 20.35504 \\
\hline Observations & 31 & 31 & 31 \\
\hline
\end{tabular}

The graphical representation of the time series associated with the study variables is given in Figure 1.

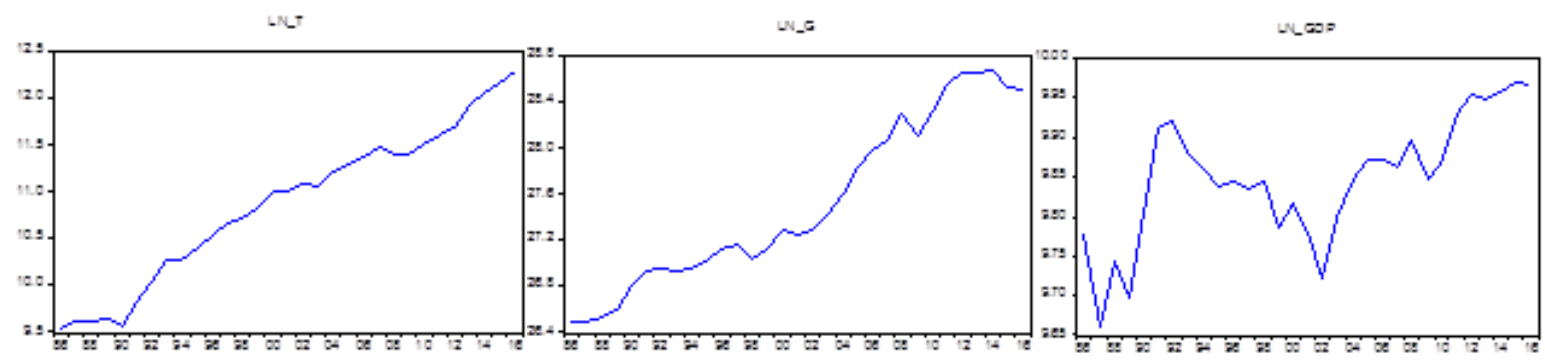

Figure 1. The graphical representation of the time series for the period of 1986-2016 


\subsection{Model Specification}

The study assumed that economic growth is impacted by higher education outputs and education expenditure. For measuring this impact, it was assumed that the function will take the following formula:

$$
L N_{G D P}=f\left(L N_{G}, L N_{T}\right)
$$

The stationarity of the time series adopted in this study was examined first, followed by a cointegration test and an estimation of the model in both the short and long run. The significance levels of 10\%, 5\% and $1 \%$ were adopted for the statistical significance and other tests. Eviews. 9 was employed as well.

To test the long-term relationship between the variables under study, an autoregressive distributed lag (ARDL) methodology was adopted, which was developed by Pesaran et al. (2001). This test is unlike other common integration tests in that it does not require the time series to be the subject of the study or integrated from the first degree; the only condition for this test is that the time series should not be integrated from the second degree or above I (2). Therefore, the self-regression method of distributed slowdown accepts stable chains at the level I (0) or integrated Class I (1) or a mixture of both.

Before the analysis of the study equation, it was necessary to ensure that the time series of the study variables were stationary, i.e., that no unit root problem existed for all the study variables. As for the next step, the ARDL cointegration test was conducted along with estimating the model in the long and short term in addition to the Granger causality test. The economic analysis of the results obtained is presented below.

The ARDL model adopted the following form:

$$
\begin{gathered}
\ln G D P_{t}=\delta_{0}+\sum_{k=1}^{n} \delta_{1 k} \Delta \ln G D P_{t-k}+\sum_{k=1}^{n} \delta_{2_{k}} \Delta \ln T_{t-k}+\sum \delta_{3_{k}} \Delta \ln G_{t-k}+\pi_{1} \ln G D P_{t-1}+\pi_{2} \ln T_{t-1}+ \\
\pi_{3} \ln G_{t-1}+\varepsilon t
\end{gathered}
$$

\section{Results}

\subsection{Stationarity Tests}

The unit root was employed to identify the degree of time series integration with the study variables, with the aim of identifying whether these variables are stationary. The Phillips-Perron test was employed in addition to testing the null hypothesis, which states that there exists a unit root (which signifies the non-stationarity of time series). Table 3 illustrates the unit root test results.

Table 3. Phillips-perron unit root test

\begin{tabular}{lllcc}
\hline At level l $(o)$ & \multicolumn{3}{l}{} & \\
\hline \multirow{2}{*}{ With Constant } & Variables & LN_GDP & LN_T & LN_G \\
\hline \multirow{2}{*}{ With Constant \& Trend } & t-Statistic & -1.5580 & 0.0537 & -0.4839 \\
\cline { 2 - 5 } & Prob. & 0.4911 & 0.9564 & 0.8810 \\
\hline Without Constant \& Trend & t-Statistic & -2.4429 & -1.9378 & -1.9322 \\
\cline { 2 - 5 } & Prob. & 0.3519 & 0.6102 & 0.6130 \\
\hline 1st Difference I(1) & t-Statistic & 0.9454 & 5.8499 & 3.1585 \\
\cline { 2 - 5 } With Constant & Prob. & 0.9042 & 1.0000 & 0.9992 \\
& & & & \\
\cline { 2 - 5 } & t-Statistic & -6.4270 & -4.6912 & -4.6407 \\
\cline { 2 - 5 } & Prob. & 0.0000 & 0.0008 & 0.0009 \\
\cline { 2 - 5 } & Significance & $* * *$ & $* * *$ & $* * *$ \\
\hline With Constant \& Trend & t-Statistic & -6.2943 & -4.5980 & -4.5509 \\
\cline { 2 - 5 } & Prob. & 0.0001 & 0.0051 & 0.0057 \\
\cline { 2 - 5 } & Significance & $* * *$ & $* * *$ & -3.6339 \\
\hline Without Constant \& Trend & t-Statistic & -6.2422 & -2.6841 & \\
\hline
\end{tabular}




\begin{tabular}{llccc}
\hline & Prob. & 0.0000 & 0.0091 & 0.0007 \\
\hline & Significance & $* * *$ & $* * *$ & $* * *$ \\
\hline
\end{tabular}

a: (*)Significant at 10\%; (**)Significant at 5\%; (***)Significant at $1 \%$ and (no) Not Significant

b: Lag Length based on SIC

c: Probability based on MacKinnon (1996) one-sided p-values

\subsection{ARDL Cointegration Test}

a. Identifying the appropriate lag period

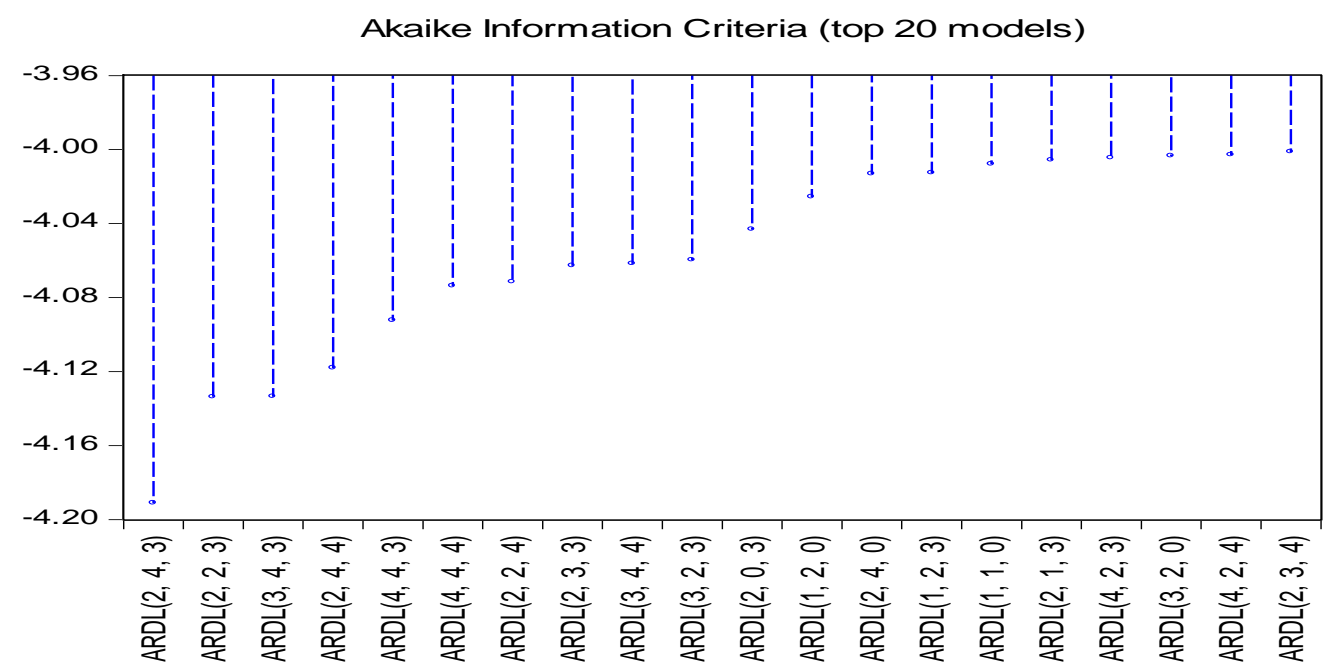

Figure 2. Results of AIC-based optimal lags test

Based on Figure 2, it is clear that according to AIC, the best models are $(2,4,3)$ ARDL for the variables LN_GDP, LN_T, and LN_G, respectively.

- $\quad$ Bounds test results: The ARDL cointegration test was based on the following two hypotheses.

- $\quad$ There exists no cointegration among variables $H_{0}: \delta_{1}=\delta_{2}=0$

- $\quad$ There exists cointegration among variables $H_{1}: \exists \delta i \neq 0$

It is a test for the common significance of the long-term parameters using Wald Test, or F-statistic. F-statistic is calculated as follows:

$$
\mathrm{F}-\text { statistic }=\frac{(\mathrm{SSER}-\mathrm{SSEU}) / \mathrm{M}}{\mathrm{SSEU} /(\mathrm{N}-\mathrm{K})}
$$

Where, SSER is the sum of squared residuals from the restricted model (applying the null hypothesis); SSEU is the sum of squared residuals from the unrestricted model; $\mathrm{M}$ is the number of the restricted model parameters; $\mathrm{N}$ is the number of observations; and $\mathrm{K}$ is the number of the unrestricted model parameters.

The F-statistic calculated was compared with the critical value already identified by Pasaran et al. (2001). For this purpose, two sets of appropriate critical values (K), which represent the number of explanatory variables and help identify whether the model has an intercept and/or a constant, were introduced. The first set assumes that all variables are stable at the level while the other set assumes that they are stable in differences. This provides bounds covering all the possible categories for the variables used in the study from 1(0) and 1(1). If the F-statistic calculated is greater than the highest maximum value of $\mathrm{F}$ tabulated, the null hypothesis stating that there exist no cointegration relationships among variables is rejected. In other words, the presence of cointegration among the variables entails a long-run equilibrium relationship among them. In case the F-statistic calculated lies between the minimum and 
maximum values of the $\mathrm{F}$ value (tabulated), it means that the results are definite, reflecting an inability to make a decision to decide whether there exists a cointegration relationship among the variables or not. The results of the ARDL bounds test are given in Table 4.

Table 4. Results of the ARDL Bounds Test

\begin{tabular}{lll}
\hline Test Statistic & Value & $\mathrm{K}$ \\
\hline F-statistic & 5.843419 & 2 \\
\hline Critical Value Bounds & & \\
\hline Significance & I0 Bound & I1 Bound \\
\hline $10 \%$ & 2.63 & 3.35 \\
\hline $5 \%$ & 3.1 & 3.87 \\
\hline $2.5 \%$ & 3.55 & 4.38 \\
\hline $1 \%$ & 4.13 & 5 \\
\hline
\end{tabular}

Source: Eviews (author' computation)

These results reveal that F-statistic (calculated) was greater than the upper bound at the significance levels of $1 \%$, $2.5 \%, 5 \%$, and $10 \%$.

Consequently, the null hypothesis stating that there exist no cointegration relationships among variables was rejected, and the alternative hypothesis stating that a long-run equilibrium relationship does exist between the dependent variable and the independent ones was accepted.

\subsection{Unrestricted Error Correction Model (UECM)}

We estimated the impact of independent variables on the dependent variable by utilizing the unconstrained error model (UECM), which required estimating the parameters of the model in the short and long term in a single equation. The model was formulated within the framework of the ARDL self-regression model, and it took the following standard form:

$$
\begin{gathered}
\ln G D P_{t}=\delta_{0}+\sum_{k=1}^{n} \delta_{1 k} \Delta \ln G D P_{t-k}+\sum_{k=1}^{n} \delta_{2_{k}} \Delta \ln T_{t-k}+\sum \delta_{3_{k}} \Delta \ln G_{t-k}+\pi_{1} \ln G D P_{t-1}+\pi_{2} \ln T_{t-1}+ \\
\pi_{3} \ln G_{t-1}+\varepsilon t
\end{gathered}
$$

$\Delta$ indicates the first differences of the variables under study, and the parameter of the dependent variable slowing down for one period to the left of the equation represents the parameters of the long-term relationship. The parameters of the first differences $(\delta)$ represent the parameters of the short period, while $\delta_{0}$ and $\varepsilon$ indicate the categorical part and random term errors, respectively. The assessment results are shown in Table 5.

Table 5. Results of UECM

\section{Dependent Variable: LN_GDP}

Method: ARDL

Included observations: 27 after adjustments

Maximum dependent lags: 4 (Automatic selection)

Model selection method: Akaike info criterion (AIC)

Dynamic regressors (4 lags, automatic): $L N \_T L N \_G$

Fixed regressors: $C$

Number of models evaluated: 100

Selected Model: ARDL (2, 4, 3)

\begin{tabular}{lllll}
\hline Variable & Coefficient & Std. Error & t-Statistic & Prob.* \\
\hline
\end{tabular}




\begin{tabular}{lllll}
\hline LN_GDP(-1) & 0.535689 & 0.226498 & 2.365090 & 0.0319 \\
\hline LN_GDP(-2) & -0.572143 & 0.227454 & -2.515418 & 0.0238 \\
\hline LN_T & 0.067406 & 0.082183 & 0.820194 & 0.4249 \\
\hline LN_T(-1) & 0.044772 & 0.096517 & 0.463872 & 0.6494 \\
\hline LN_T(-2) & -0.129923 & 0.092145 & -1.409985 & 0.1789 \\
\hline LN_T(-3) & 0.058395 & 0.099632 & 0.586106 & 0.5665 \\
\hline LN_T(-4) & -0.160308 & 0.087402 & -1.834147 & 0.0865 \\
\hline LN_G & 0.119889 & 0.059813 & 2.004411 & 0.0634 \\
\hline LN_G(-1) & -0.012799 & 0.086670 & -0.147672 & 0.8846 \\
\hline LN_G(-2) & -0.055553 & 0.081047 & -0.685434 & 0.5035 \\
\hline LN_G(-3) & 0.133962 & 0.052959 & 2.529553 & 0.0231 \\
\hline C & 6.370679 & 2.012748 & 3.165164 & 0.0064 \\
\hline
\end{tabular}

\begin{tabular}{llll}
\hline R-squared & 0.903571 & Mean dependent var & 9.867668 \\
\hline Adjusted R-squared & 0.832856 & S.D. dependent var & 0.062629 \\
\hline S.E. of regression & 0.025605 & Akaike info criterion & -4.190974 \\
\hline Sum squared resid & 0.009834 & Schwarz criterion & -3.615046 \\
\hline Log likelihood & 68.57814 & Hannan-Quinn criterion & -4.019720 \\
\hline F-statistic & 12.77769 & Durbin-Watson stat & 2.117680 \\
\hline Prob(F-statistic) & 0.000011 & & \\
\hline
\end{tabular}

*Note: p-values and any subsequent tests do not account for model selection.

The following is an evaluation of the results of the UECM estimate:

\subsubsection{Statistical Criteria}

A. Significance of the Parameters Test: To implement the parameter significance test, it was sufficient to compare the calculated probability with a 0.05 level of significance to choose one of the two hypotheses. If the probability was less than 0.05 , we would reject the null hypothesis that says that the parameter has no statistical significance and accept the alternative hypothesis that the parameter is statistically significant, and vice versa. Accordingly, we noticed that the constant was statistically significant at $5 \%$ level of significance.

R-Squared Coefficient: We noted that the determination factor was estimated at R2 $=0.90357$, which was acceptable since the change value of the independent variables could explain $90.35 \%$ of the changes that occur to GDP, which means that there is a strong correlation between LN_GDP \& LN_T \& LN_G.

B. Fisher Test: To check whether the value of the coefficient R2 obtained above is an objective value, we used the Fisher test to test the overall significance of the model and, via the above table, we obtained the Fisher value $\mathrm{F}=$ 12.77 and the probability Prob $(\mathrm{F}$-statistic $)=0.000$. We, therefore, rejected the null hypothesis, which states that all independent parameters are equal to zero, and supported the alternative hypothesis that at least one parameter is not equal to zero, which means that the Fisher test was statistically significant at 5\%.

\subsubsection{Standard Criteria}

A. Error Normality Distribution Tetst: This test is used to verify the normal distribution of residuals, which was proved by the model as per the Jarque-Bera value with a probability of $(0.768)$. This led us to accept the null hypothesis, which shows that the regression equation residuals follow a normal distribution. 


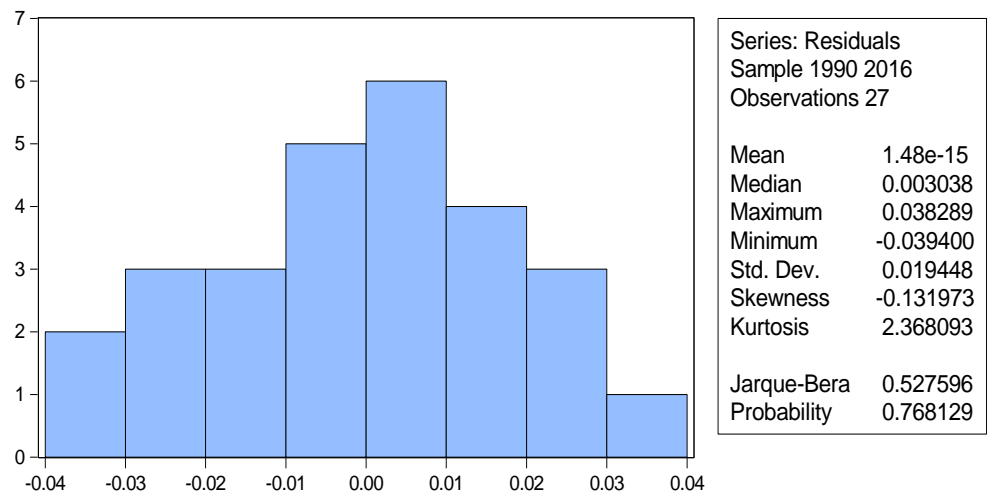

Figure 3. Results of Normality Distribution Test

B. Multi-Collinearity among independent variables:

Table 6. Results of breusch-godfrey serial correlation LM test

\begin{tabular}{llll}
\hline F-statistic & 0.127900 & Prob. F(2,13) & 0.8810 \\
\hline Obs*R-squared & 0.521026 & Prob. Chi-Square(2) & 0.7707 \\
\hline
\end{tabular}

We observed with the Breusch-Godfrey test the linear multiplicity problem between the variables, which explained that prob $=0.8810>0.1$. Thus, the computed value was smaller than the tabular value. We then accepted the null hypothesis, which implies that there is no linear multiplicity between the variables explained in the model.

\subsection{Heteroskedasticity Test}

It is as shown in the Table 7.

Table 7. Results of heteroskedasticity test: ARCH

\begin{tabular}{llll}
\hline F-statistic & 1.025405 & Prob. F(1,24) & 0.3213 \\
\hline Obs*R-squared & 1.065338 & Prob. Chi-Square(1) & 0.3020 \\
\hline
\end{tabular}

From the results of the ARCH variance stability test, the probability was to be equal to 0.3213 , which is greater than the significance level of $1 \%, 5 \%$, and $10 \%$; thus, we determined that the model does not suffer any variance.

\subsection{Results of UECM and Long-Run Equilibrium}

Table 8 shows that the change in (D (LN_T(-1), D(LN_T(-3), D(LN_G), and D(LN_G(-2) exercises a significant impact on LN_GDP. The short-term elasticity shows that increasing D (LN_T(-1) algorithm of the total graduates by one lag of $100 \%$ leads to an increase in LN_DGP by 23.18\%. Further, increasing D (LN_T (-3) algorithm of the total graduates by three lags of $100 \%$ leads to an increase in LN_DGP by $16.03 \%$. Increasing D (LN_G) algorithm of education expenditure by $100 \%$ can lead to an increase in LN_DGP by $11.98 \%$. Additionally, increasing D (LN_G (-2)) algorithm of education expenditure of two lags by $100 \%$ can lead to an increase in LN_DGP by $13.39 \%$. This reveals a direct relationship between higher education outputs and economic growth along with education expenditure and economic growth in the short run. ECM results revealed that ECT rapidly detects the speed by which economic growth variable goes back towards its equilibrium value in the long run, wherein each period witnesses a state of non-equilibrium in the period (t-1) estimated by $(-1.03)$ This is considered to be a very high correction coefficient. Also, the significance of ECT is evident at 1\%, confirming a cointegration relation among the variables In_G, In-T, and ln_GDP. 
Table 8. Results of ECNM and long-run equilibrium

\begin{tabular}{|c|c|c|c|c|}
\hline \multicolumn{5}{|c|}{ ARDL Cointegrating and Long-Run Form } \\
\hline \multicolumn{5}{|c|}{ Dependent Variable: LN_GDP } \\
\hline \multicolumn{5}{|c|}{ Selected Model: $\operatorname{ARDL}(2,4,3)$} \\
\hline \multicolumn{5}{|c|}{ Sample: 19862016} \\
\hline \multicolumn{5}{|c|}{ Included observations: 27} \\
\hline Variable & Coefficient & Std. Error & t-Statistic & Prob.* \\
\hline D(LN_GDP(-1)) & 0.572143 & 0.190443 & 3.004272 & 0.0089 \\
\hline $\mathrm{D}\left(\mathrm{LN} \_\mathrm{T}\right)$ & 0.067406 & 0.059066 & 1.141196 & 0.2717 \\
\hline $\mathrm{D}\left(\mathrm{LN} \_\mathrm{T}(-1)\right)$ & 0.231836 & 0.069578 & 3.332036 & 0.0045 \\
\hline$\overline{\mathrm{D}\left(\mathrm{LN} \_\mathrm{T}(-2)\right)}$ & 0.101913 & 0.069448 & 1.467468 & 0.1629 \\
\hline $\mathrm{D}\left(\mathrm{LN} \_\mathrm{T}(-3)\right)$ & 0.160308 & 0.056370 & 2.843854 & 0.0123 \\
\hline$\overline{D\left(L N \_G\right)}$ & 0.119889 & 0.044460 & 2.696549 & 0.0166 \\
\hline D(LN_G(-1)) & -0.078410 & 0.060183 & -1.302846 & 0.2123 \\
\hline D(LN_G(-2)) & -0.133962 & 0.044568 & -3.005809 & 0.0089 \\
\hline CointEq(-1) & -1.036454 & 0.195702 & -5.296075 & 0.0001 \\
\hline \multicolumn{5}{|c|}{ Cointeq $=L N \_G D P-\left(-0.1154 * L N \_T+0.1790 * L N \_G+6.1466\right)$} \\
\hline \multicolumn{5}{|c|}{ Long-Run Coefficients } \\
\hline Variable & Coefficient & Std. Error & t-Statistic & Prob. \\
\hline LN_T & -0.115450 & 0.025614 & -4.507232 & 0.0004 \\
\hline LN_G & 0.178975 & 0.027154 & 6.591120 & 0.0000 \\
\hline $\mathrm{C}$ & 6.146610 & 0.482377 & 12.742334 & 0.0000 \\
\hline
\end{tabular}

From Table 8 it also appears that the outputs of education have a negative impact on GDP per capita, which means that there is a negative correlation between variables because the Education Outputs coefficient is -0.11 .

As far as spending on education is concerned, it has a positive impact on economic growth, which means that there is a positive relationship between the two variables, because that the Education Expenditure coefficient is 0.179.

These findings indicate that public spending in education has a positive and significant impact on economic growth in the long run. Furthermore, he observed that a $1 \%$ increase in public expenditure in education contributes $18 \%$ increase in GDP per capita in the long run.

\subsection{Goodness-of-Fit Test}

Based on the Ramsey regression equation specification error test (RESET), the model did not suffer from any issue of lack of fit. Therefore, it is true if we get $\mathrm{F}$ value of 4.3 , which is insignificant, when its probable value is $(0.0568)$. This leads to accepting the null hypothesis, which states that the function does not suffer from any misspecification.

Table 9. Ramsey RESET test

\begin{tabular}{|c|c|c|c|}
\hline Equation: & & & \\
\hline Specificat & N_GDP(-1 & $\mathrm{LN}_{-}$ & LN_T LN_T(-1) LN_T( \\
\hline -2) LN_T( & N_G LN_C & $-1) \mathrm{I}$ & LN_G(-3) C \\
\hline Omitted V & es of fitted & lues & \\
\hline & Value & $\mathrm{df}$ & Probability \\
\hline t-statistic & 2.075640 & 14 & 0.0568 \\
\hline
\end{tabular}




\begin{tabular}{llll}
\hline F-statistic & 4.308282 & $(1,14)$ & 0.0568 \\
\hline F-test summary: & & & \\
\hline & Sum of Sq. & df & Mean Squares \\
\hline Test SSR & 0.002314 & 1 & 0.002314 \\
\hline Restricted SSR & 0.009834 & 15 & 0.000656 \\
\hline Unrestricted SSR & 0.007520 & 14 & 0.000537 \\
\hline
\end{tabular}

\subsection{Stability Test of ARDL-ECM}

To ensure that the data used in the study were void of any structural changes, the appropriate tests were employed, namely CUSUM and CUSUM of squares.

The structural stability of the estimated coefficients of the error correction model of the ARDL is achieved when the chart of CUSUM and CUSUM of squares lie within the critical values at 5\%. Based on the majority of studies, both tests proposed by Brown et al. (1975) were conducted.

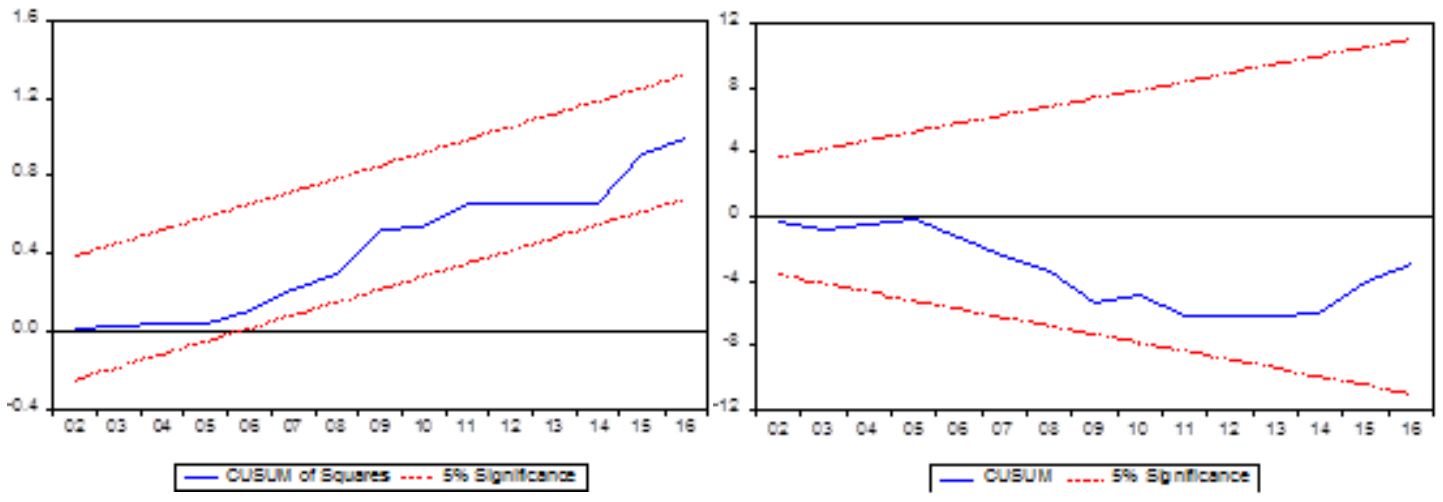

Figure 4. Chart of CUSUM and CUSUM of squares

\section{Conclusion}

To measure the impact of education outputs (number of graduates) and education expenditures on economic growth in the Kingdom of Saudi Arabia, we first employed the ARDL cointegration test, and then we investigated the stationarity of the time series under study to ensure that all the series were stable in the first differences, according to the results of the Philipps - Perron test. After estimating the cointegration, the results revealed the existence of a long-term relationship between the variables. The parameter of the number of graduates in the long term was negative and significant; This signifies the existence of an inverse relationship. This relationship is explained by several interpretations, some of which are: poor educational attainment and poor quality of education, although the average years of schooling have increased over the years, but the quality of education and the level of students in decline. This is in addition to the incompatibility of the outputs of the education system with the labor market, and a large number of graduates of the education system suffer from unemployment or work in specialties far from their specialization.

The latter was confirmed by Jeddah Chamber (2016) whose report estimated the youth unemployment rate at $42 \%$ in 2014. while this parameter is positive and not significant in the short term.

As far as spending on education is concerned, it has a positive impact on economic development, which means that there is a positive relationship between the two variables, because that the Education Expenditure coefficient is 0.179 .

These findings indicate that public spending in education has a positive and significant impact on economic growth in the long run. Furthermore, he observed that a $1 \%$ increase in public expenditure in education contributes $18 \%$ increase in GDP per capita in the long run. 
The UECM showed the ability to return to the point of equilibrium and to adapt in the long term. The model further achieved the structural stationarity of the estimated coefficients of error correction for the autoregression model for distributed time gaps. This indicates that the education expenditure in the Kingdom of Saudi Arabia has a direct effect on economic growth. This is consistent with the Keynesian theory and previous studies.

Through this study, we concluded that a long-term relationship is present between education outcomes, education expenditures, and economic growth in the Kingdom of Saudi Arabia.

Based on the findings, we present the following recommendations:

- Linking the needs of the market and the educational system, it is clear that coordination between the Saudi educational system and the labor market at the highest levels is necessary.

- Attention should be paid to the continuity and quality of education, as education achieves full objectives by providing continuity through the permanence of learning and training.

- In the field of higher education, it is necessary to grant universities the flexibility and freedom to open departments and specializations in line with the needs of the labor market.

In the Saudi Arabian context, additional research should focus on the impact of the stages that precede university education (elementary, middle, and high school) and consider it a prerequisite for higher education. Determining the outputs of the specializations, such as engineering, and ascertaining which ones are the most influential on economic growth as well as the implications of this relationship will be imperative for Saudi Arabia's target of Saudization in many areas.

\section{References}

Aghion, P., Meghir, C., \& Vandenbussche, J. (2006). Growth, distance to frontier and composition of human capital. Journal of Economic Growth, (11), 97-127. https://doi.org/10.1007/s10887-006-9002-y

Albassam, A. (2015). Economic diversification in Saudi Arabia: Myth or reality? Resources Policy, (44), 112-117.

Almawishir, N. (2018). The role of institutional support in influencing SME growth: The case of Saudi Arabia. PHD thesis, Faculty of Business and Law, Department of Economics, Policy and International Business, Manchester Metropolitan University (pp. 94-116).

Alo, L., \& Kärt, R. (2017). How higher education institutions contribute to the growth in regions of Europe?. Studies in Higher Education, 42(01), 65-78. https://doi.org/0.080/03075079.205.034264

Alvina, I., \& Muhammad, S. (2013). Does public education expenditure cause economic growth? Comparison of developed and developing countries. Pakistan Journal of Commerce and Social Sciences, 7(1), 74-83.

Balaev, M. (2014). Improving models of democracy: The example of lagged effects of economic development, education, and gender equality. Social Science Research, 46, 169. https://doi.org/10.1016/j.ssresearch.2014.03.004

Barro, J., \& Sala-i-Martin, X. (2003). Economic growth (2nd ed.). The MIT Press.

Barro, R. (1991). Economic growth in a cross-section of countries. Quarterly Journal of Economics, 106(2), 407-443. https://doi.org/10.2307/2937943

Bassanini, A., \& Scarpetta, S. (2001). Does human capital matter for growth in OECD countries? Evidence from pooled mean-group estimates. OECD Economics Working Paper No. 282.

Becker, G. (1964). Human capital: A theoretical and empirical analysis, with special reference to education (3rd ed.). The University of Chicago Press.

Benhabib, J., \& Spiegel, M. (1994). The role of human capital in economic development: Evidence from aggregate cross-country data. Journal of Monetary Economics, 34(2), 143-173.

Bils, M., \& Klenow, J. (2000). Does schooling cause growth?. American Economic Review, 90(5), 1160-1183.

Bouzahzah, M., De la Croix, D., \& Docquier, F. (2002). Policy reforms and growth in computable OLG economies. Journal of Dynamics and Control, 26, 2093-2113.

Brauninger, M., \& Vidal, P. (1999). Private versus public financing of education and endogenous growth. Journal of Population Economics, 13(3), 387-401.

Çalışkan, Ş., Karabacak, M., \& Oytun, M. (2013). Türkiye'de Eğitim-Ekonomik Büyüme İlişkisi: 1923-2011 (Kantitatif Bir Yaklaşım). Yönetim Bilimleri Dergisi, 21(11), 29-48. 
Carayannis, G., \& Campbell, J. (2009). 'Mode 3' and 'Quadruple Helix': Toward a 21st century fractal innovation ecosystem. International Journal of Technology Management, 46(3/4), 201-234.

Castelló-Climent, A., \& Doménech, R. (2008). Human capital inequality, life expectancy and economic growth. The Economic Journal, 118(528), 653-677.

Chamber, J. (2016). Saudi Arabia- manpower \& employment, talent management, and compensation report.

Cohen, D., \& Soto, M. (2007). Growth and human capital: Good data, good results. J Econ Growth, 12(1), 51-76. https://doi.org/10.1007/s10887-007-9011-5

Devarajan, S., Swaroop, V., \& Zou, H.-F. (1996). The composition of public expenditure and economic growth. Journal of Monetary Economics, 37(2), 313-344.

Fantin, M. (2016). OPEC Annual statistical bulletin 2016 (51st ed.). Retrieved November 12, 2020, from www.opec.org/opec_web/en/publications/202.htm

Glaeser, L., La Porta, R., Lopez-de-Silanes, F., \& Shleifer, A. (2004). Do institutions cause growth?. Journal of Economic Growth, 9(3), 271-303.

Gustafsson, B., \& Li, S. (2004). Expenditures on education and health care and poverty in rural China. China Economic Review, 15(3), 292-301.

Gylfason, T., \& Zoega, G. (2003). Education, social equality and economic growth: A view of the landscape. CESifo Economic Studies, 49(4), 557-579.

Holm-Nielsen, B., Thorn, K., Olesen, D., \& Huey, T. (2013). Talent development as a university mission: The quadruple helix. Higher Education Management and Policy, 24(2), 99-113.

Jang, J., \& Lawrence, J. (2014). On the relationship between university education and economic growth: The role of professors' publication. Education Economics, 22(6), 635-651. https://doi.org/10.1080/09645292.2012.697646

Jones, C. (1998). Introduction to economic growth. W.W. Norton Co.

Jong-Suk, H., \& Jong-Wha, L. (2020). Demographic change, human capital, and economic growth in Korea. Japan \& The World Economy, 53, 1-12. $\quad$ Retrieved from https://linkinghub.elsevier.com/retrieve/pii/S0922142519300428

Jorgenson, W., Gollop, F., \& Fraumeni, M. (1987). Productivity and U.S. economic growth. Harvard University Press.

Keller, R. I. (2006). Education expansion, expenditures per student and the effects on growth in Asia. Global Economic Review, 35(1), 21-42.

Krueger, A. B., \& Lindah, M. (2001). Education for growth: Why and for whom?. Journal of Economic Literature, 39(4), 1101-1136.

Levine, R., \& Renelt, D. (1992). A sensitivity analysis of cross-country growth regressions. The American Economic Review, 82(4), 942-963.

Lingaraj, M., \& Devi, D. (2015). Does expenditure on education affect economic growth in India? Evidence from cointegration and granger causality analysis. Theoretical and Applied Economics, 4(605), 63-74.

Lingaraj, M., Pradeep, D., \& Kalandi, P. (2016). Impact of educational expenditure on economic growth in major Asian countries: Evidence from econometric analysis. Theoretical and Applied Economics, 23(2), 173-186.

Lipset, S. (1960). Political man: The social bases of politics. Doubleday.

Lucas Jr, R. E. (1988). On the mechanics of economic development. J. Monet. Econ., 22(1), 3-42.

Manafi, I., \& Marinescu, D. E. (2013). The influence of investment in education on inclusive growth-empirical evidence from Romania vs EU. Procedia-Social and Behavioral Sciences, (93), 689-694. https://doi.org/10.1016/j.sbspro.2013.09.262

Mankiw, G., Romer, D., \& Weil, N. (1992). A contribution to the empirics of economic growth. The Quarterly Journal of Economics, 107(2), 407-437.

Mehmet, M., \& Sevgi, S. (2014). The effect of education expenditure on economic growth: The case of Turkey, 2nd World Conference on Business, Economics and Management - WCBEM2013. Procedia - Social and Behavioral Sciences, 109, 925-930. https://doi.org/10.1016/j.sbspro.2013.12.565 
Mercan, M., \& Sezer, S. (2014). The effect of education expenditure on economic growth: The case of Turkey. Procedia-Social and Behavioral Sciences, 109, 925-930.

Mpho, B. (2015). Payoffs of education expenditure in Botswana: Long run economic growth implications. Journal of Applied Economics and Business Research, 5(2), 85-96.

Ojala, D. O. (2016). Role of educational investment on economic growth and development in Kenya. Journal of Education and Practice, 7(22), 68-81.

SAMA. (2016). Saudi Arabian Monetary Authority (SAMA). SAMA. Retrieved November 18, 2020, from http://www.sama.gov.sa/en-US/Pages/default.aspx

Sanchez, M., \& Cicowiez, M. (2014). Trade-offs and Pay offs of investing in human development. World Development, 62, 14-29.

Schultz, T. W. (1961). Investment in human capital. American Economic Review, 61, 1-17.

Sefa, C., Mehmet, U., \& Siew, L. Y. (2017). Government education expenditures and economic growth: A meta-analysis. The B.E. Journal of Macroeconomics, 17(2). https://doi.org/10.1515/bejm-2016-0109

Sergio, B., Daniel, M., \& Gilberto, T. (2009). Healthy, educated and wealthy: A primer on the impact of public and private welfare expenditures on economic growth. The Journal of Socio-Economics, (38), 946-956. https://doi.org/10.1016/j.socec.2009.06.013

Shahriyar, M., Ilkin, M., \& Sugra, H. (2020). The relationship between government expenditures on education and economic growth: The case of Azerbaijan. Research in World Economy, 11(1). https://doi.org/10.5430/rwe.v11n1p195

Takii, K., \& Tanaka, R. (2009). Does the diversity of human capital increase GDP? A comparison of education systems. Journal of Public Economics, 93, 998-1007.

Telatar, O., \& Ve Terzi, H. (2010). Nüfus ve Eğitimin Ekonomik Büyümeye Etkisi: Türkiye Üzerine Bir İnceleme, Atatürk Üniversitesi, İ̈BF. Dergisi, 24(2), 197-214.

Temple, J. (1999). A positive effect of human capital on growth. Economics Letters, 65, 131-134.

Wozniak, D. G. (1987). Human capital, information, and early adoption of new technology. The Journal of Human Resource, 22(1), 101-112.

Wulong, G., \& Ambrose, W. (2015). Productivity and economic output of the education sector. J Prod Anal, 43, 165-182. https://doi.org/10.1007/s11123-014-0414-y

Yousif, K. (2008). Education expenditure and economic growth: Some empirical evidence from the GCC countries. The Journal of Developing Areas, 42(1), 69-80. Retrieved from https://www.jstor.org/stable/40376194

Zhang, J. (1996). Optimal public investment in education and endogenous growth. Scandinavian Journal of Economics, 98(3), 387-404.

\section{Copyrights}

Copyright for this article is retained by the author(s), with first publication rights granted to the journal.

This is an open-access article distributed under the terms and conditions of the Creative Commons Attribution license (http://creativecommons.org/licenses/by/4.0/). 